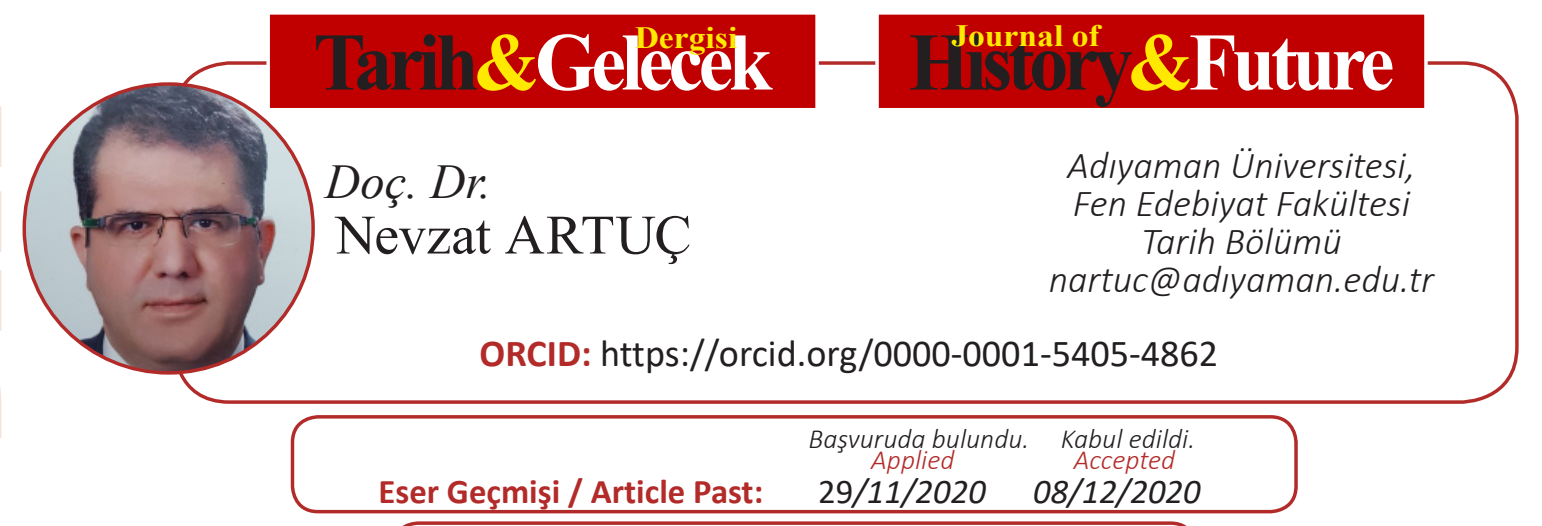

Araştırma Makalesi

DOI: http://dx.doi.org/10.21551/jhf.833103

Research Paper

Orjinal Makale / Orginal Paper

\title{
II. Meşrutiyet Dönemi’nde Bağdat Vilayet İdaresinde Yaşanan Değişim Ve Gelişmeler
}

\author{
Changes and Developments in Baghdad Provincial Administration in \\ the Second Constitutional Period
}

$\ddot{\mathbf{O} z}$

Osmanlı Devleti, Tanzimat Döneminden itibaren Bağdat ve havalisi için özel yönetim tedbirleri almıştır. Özellikle bölgede tesis edilen VI. Ordu Komutanlığı ve Midhat Paşa’nın Bağdat Valiliği sırasındaki başarılı icraatları dikkatlerin bir kez daha bölge üzerinde yoğunlaşmasına sebebiyet vermiştir. II. Meşrutiyet Döneminde de emperyalist faaliyetlere karşı Bağdat ayrıcalıklı önemini muhafaza etmiş, Ordu Komutanlığı ve Valilik görevleri tevcihinde son derece hassas davranılarak bölgedeki otorite boşluğu doldurulmaya çalışılmıştır. Ancak, Osmanlı Devleti’nin Birinci Dünya Savaşı'na dahil olmasıyla birlikte Bağdat vilayet idaresinde köklü değişiklikler oldu. Bağdat Vilayeti daha çok askeri bir mahiyet kazandı. Savaşta İngilizlerin en büyük hedefi haline geldi. Selman-1 Pak ve Kûtü'l-Amâre'de kazanılan tarihi başarılar İngilizlerin hevesine engel oldu. Ancak, Almanya'nın bölgede kendi menfaatleri doğrultusundaki çalışmaları ve bürokraside yaşanan yetki tartışmaları İngiliz tehdidi karşısında yeterli önlemlerin alınamamasına neden olmuştur. Nitekim İngilizler yaklaşık 10 ay gibi kısa sayılabilecek bir içerisinde önce Kûtü'l-Amâre'yi ardından Bağdat'1 alarak Türk-Alman anlaşmazlığından istifade etmesini bilmiştir. Almanların Bağdat'1 kurtarmak için planladıkları Yıldırım Orduları Grup Kumandanlığı projesi de Bağdat'ı kurtarmak için yeterli olmamıştır.

Anahtar Kelimeler: Bağdat, Almanya, Kûtü’l-Amâre, Selman-1 Pak, Goltz Paşa, Cemal Paşa, Halil Paşa

\section{Abstract}

The Ottoman State had taken special management precautions for Baghdad and its vicinity since The Period of The Tanzimat. Especially, the formation of the VI. Army command in the region and the successful performances of Midhat Pasha during his Baghdad governership once again caused that attention be focused on the region. Also during the II. Constitutionalist Period against the emperialist activities Baghdad preserved its privileged position and the Ottoman State being meticulous about 
conferring the army commandment and governership posts tried to fill the authority gap in the region. However, with the inclusion of the Ottoman State in the First World War, there were radical changes in the province of Baghdad. Baghdad Province became more of a military character. It became the greatest target of the British in the war. Historical successes in Selman Pak and Kûtü'lAmâre prevented the desire of the British. However, Germany's efforts towards its own interests in the region and the debates on authority in the bureaucracy have caused inadequate measures to be taken against the British threat. As a matter of fact, the British were able to take advantage of the Turkish-German conflict by taking Kûtü'l-Amâre and then Baghdad in a short period of about 10 months. The Yildırım Armies Group Command project planned by the Germans to save Baghdad was not enough to save Baghdad.

Key Words: Baghdad, Germany, Kûtü'l-Amâre, Selman-1 Pak, Goltz Pasha, Cemal Pasha, Halil Pasha

\section{Giriş}

II. Abdülhamid Dönemi'nde Bağdat'ta uygulamaya sokulan eşraf siyaseti, II. Meşrutiyet'in ilanıyla birlikte çökmüştür. İttihatçılar Bağdat'ta eşrafi, II. Abdülhamid sisteminin bir devamı olarak görmüşler bu yüzden onlara verilen bütün ayrıcalıkları kaldırmışlardır. II. Meşrutiyet'in ilanı bu yüzden Irak’ta hoşnutsuzlukla karşılanmıştır. Eşrafa yapılan muamele, isyanla sonuçlanmıştır. Midhat Paşa'nın izinden gitmeyi tercih eden İttihatçılar, meşihat usulünün kaldırılmasını ve arazinin yeniden küçük parçalar halinde halka dağıtılmasını ön görmüşlerdir ${ }^{1}$. Bu husus bölgede valilik yapan Süleyman Nazif ve Celal Beyler tarafından hazırlanan raporlarda sıklıkla ifade edilmiştir². İttihatçılar, Bağdat ve çevresinde yeniden ihya edilen sanayi mektepleri projeleriyle de Midhat Paşa'nın mirasına sahip çıktıklarını göstermişlerdir³

Meşruti sisteme geçişte yaşanan otorite boşluğu, Basra'da Şiilik faaliyetlerinin artmasına neden olmuştur. İngiliz Lynç Şirketi'ne, 1909'da Fırat ve Dicle üzerinde seyr-i sefain imtiyaz hakkının verilmesi ve 1913 'te miri arazilerin yabancılara satışı için Hükümet'in başlatmış olduğu girişimler tepkiyle karşılandı. Eşraf, Abdülhamid ve İttihatçı yanlısı şeklinde kendi aralarında gruplaşmaya başladı. Öte yandan iç siyasi çekişmeler İstanbul'dan sonra, Bağdat ve çevresinde de etkisini göstermeye başladı. Bağdat ve Basra'da 1911'de Mutedil Hürriyetperveran Fırkası'nın şubeleri açıldı. Ertesi yıl ise Hürriyet ve İtilaf Fırkası'nın Bağdat'taki örgütlenmesi tamamlandı. Basra'da Arapçılık faaliyetleri ve Prens Sabahaddin Bey'in âdem-i merkeziyet fikirleri etrafinda toplanılmaya başlandı. Basın yayım faaliyetlerinde adeta büyük bir patlama yaşandı. Bağdat'ta Meşrutiyet öncesi sadece üç resmî gazete yayın hayatında iken, 1908-1914 arası toplam altmış dokuz gazete ile on yedi dergi yayınland. ${ }^{4}$. İttihatçıların Bağdat'ta gerçekleştirmeye çalıştıkları arazi reform teşebbüslerinin başarısız olmasının nedenlerini, Birinci Dünya Savaşı'nın çıkmış

1 Gökhan Çetinsaya, "Irak XIX. Yüzyıl”, TDVİA, Yıl: 1999, C. 19, s. 94.

2 Burcu Kurt, "Meşihat Usulü’nün Ilgası: II. Meşrutiyet Dönemi Basra Vilayeti’nde Toprak reformu Teşebbüsleri”, OTAM, Sa. 37, Bahar 2015, s. 232-233.

3 Burcu Kurt, "Modernleşen Sanayi'ye Ayak Uydurmak: Osmanlı Irak'1nda Kurulan Sanayi Mektepleri”, History Studies, Vol:5, İssue: 3, May 2013, s. 170.

4 Çetinsaya, a.g.m., s. 94-95. 
olması ve bölgedeki aşiret yapısının kırılamamış olmasında aramak daha doğru olacaktır 5 .

II. Abdülhamid ve II. Meşrutiyet Dönemi’nde Irak’a yönelik iki büyük devletin tehdidi söz konusudur. İran yönetimi, bütün Osmanlı Tarihi boyunca olduğu gibi Tanzimat'tan sonraki dönem için de Bağdat'ta büyük bir tehdit oluşturmuştur. İran'ın bölgeye yönelik Şiilik propagandaları çatışmaların daha da alevlenmesine neden olmuştur. Öte yandan İngiltere XIX. Yüzyıl sonunda Hindistan yolunun güvenliğini sağlamak amacıyla öncelikle Mısır'a yerleşmiştir. Daha sonra da benzer kaygılarla bir diğer stratejik nokta olan Basra Körfezi'ne hakimiyet için bölgeye olan ilgisini artırmıştır ${ }^{6}$.

\section{A-Birinci Dünya Savaşı'na Kadar Bağdat Vilayet İdaresi}

II. Meşrutiyet Dönemi'nde Bağdat Vilayeti, Bağdat, Kerbela ve Divaniye sancaklarından oluşmaktaydı. Bağdat Sancağı'na bağl1; Bağdat, Kazımiye, Samerra, Horasan, Hanikin, Müneddili, Bedre, Kût'ül- Amâre, Aziziye, Cezire, Dilim ve Anha isimli on iki kaza, Kerbela Sancağı'na bağl1; Kerbela, Hindiye, Necef, Razaza isimli dört kaza, Divaniye sancağına bağli; Divaniye, Hala, Şamiye Semaviye isimli üç kaza bulunmaktaydı. Vilayetin nüfus çoğunluğunu Müslüman Hanefi-Şafi- Caferi Arap, Türk ve Kürtler oluşturmaktaydı. Geriye kalan kısmı Hıristiyan Ermeni, Keldani, ve Süryani cemaatleriyle birlikte Museviler oluşturmaktayd1 ${ }^{7}$. Bağdat-Basra arasındaki seyr-i sefain idare-i nehriyye'ye ait Hamidiye, Burhaniye, Musul, Fırat, Bağdat, Risaka ve Bağdat-1 Basra vapurları ile Lynç Kumpanyası'na ait Mecidiye ve Halife adlı vapurlar tarafından gerçekleştirilmekteydi ${ }^{8}$. Bağdat’ta temel sorunlar; uzun yıllardır çözüme kavuşturulamamış arazi meselesi, İran ve İngiltere ile yaşanan nüfuz mücadelesi, eşkıyalık hareketleri, aşiretler arası mücadele ve iç siyasal çekişmeler nedeniyle ortaya çıkan istikrarsızlıktır. Rumeli Kazaskeri Necmeddin Molla' dan sonra Bağdat'a atanan ikinci vali olan Mirliva Mehmed Şevket Paşa, söz konusu sorunların üstesinden gelemediği için sekiz ay yirmi altı gün gibi kısa sürede gözden düşmüş ve görevden alınmıştır ${ }^{10}$. Yerine, VI. Ordu Kumandanlığı da uhdesinde olmak kaydıyla, 25 Kasım 1909'da Nazım Paşa tayin edilmiştir. Oldukça geniş yetkilerle göreve getirilen Birinci Ferik Nazım Paşa ${ }^{11}$, öncelikle bölgede var olan otorite boşluğunu doldurmuş, güvenliği sağlayacak yegâne kurum VI. Ordu'yu yeniden düzenlemiş, vilayet jandarma kuvvetini artırmış, isyancı aşiretlerin devletle olan sorunlarını çözmede mesafe kat etmiş, Fırat-Dicle üzerindeki seyr-i sefaini düzenlemiştir. Nazım Paşa, Bağdat’ta açıkça İngiltere aleyhinde faaliyetlerde bulunmuş, İngiliz

5 Kurt, "Meşihat Usulü’nün Ilgası”, s. 235.

6 Çetinsaya, a.g.m., s. 95.

7 Bağdat Vilayet Salnamesi 1329 (1913), s. 327-332; Nevzat Artuç, "Osmanlı Devleti'nin Son Dönem Irak politikasına Bir Örnek: Nazım Paşa’nın Bağdat Valiliği (25 Kasım 1909-15 Mart 1911), Belleten, C. LXXIV, Sa. 271, Aralık 2010, s. 840.

$8 \quad$ Bă̆dat Vilayet Salnamesi 1329 (1913), s. 171.

9 İttihat ve Terakki Cemiyeti'nin önde gelen isimleri arasında yer alan Necmeddin Molla, Şeyhülislam Turşucuzade Ahmet Muhtar Efendi'nin oğlu olarak 1875'de İstanbul'da doğmuştur. Hukuk tahsilinin ardından hakimlik yapmıştır. II. Meşrutiyet’in ilanından sonra Bağdat Valiliğine, kısa bir süre sonra da Adliye Nazırlı̆̆ına tayin edildi. Necmeddin Molla, Bağdat'ta üç ay yirmi sekiz gün görev yapmıştır. Millî Mücadele'den sonra Kastamonu milletvekili olarak TBMM'ye girmiş, 1949 yılında da vefat etmiştir. Şerif Paşa, Bir Muhalifin Hatıraları Nehir Yay., İstanbul 1990, s. 120; Bağdat Vilayet Salnamesi 1329 (1913), s. 309.

10 Bağdat Vilayet Salnamesi 1329, (1913), s. 309.

11 BOA, DH. MUI, 1/9, 9 Rebiülahir 1328 (19 Nisan 1910). 
vatandaşlarına ait binaları yıktırmış, Tanin Gazetesi'nde İngiltere aleyhine çıkan yazılara destek vermiştir. Bu durum İngiltere tarafından tepkiyle karşılanmıştır. Yaklaşık olarak 16 ay gibi çok kısa süre zarfında gerçekleştirilen icraatlar, bölge halkı tarafından takdirle karşılanmış ve tıpk1 Midhat Paşa gibi, Nazım Paşa da Nazım el Irak gibi özel bir sıfatla anılır olmuştur ${ }^{12}$.

İlginçtir ki II. Meşrutiyet Dönemi bütün Bağdat Valileri İngiliz emperyalizmine karşı ortak bir duruş sergileyerek açıkça cephe almışlardır. Konuya ilişkin Hariciye Nezareti tarafından hazırlanan bir raporda, Bölgede İngilizler ile ilişkilerin bozulma nedeni, olarak; öncelikle İngilizlerin, 1881 'de Mısır'1 işgal ederek bölgeye kalıcı olarak yerleşmesi, buna misilleme olarak II. Abdülhamid'in, 1903 tarihli fermanıyla, Konya Demiryolu'nun Bağdat ve Basra’ya ulaştırılması işini Alman sermayedarlar tarafından kurulan Anadolu Kumpanyası'na verilmesi gösterilmiştir ${ }^{13}$.

II. Meşrutiyet' in ilanının ardından yaşanan belirsizliğin etkisiyle Bağdat ve çevresinde halkın can, mal ve ırzına tasallut eden adi eşkıyalık hareketlerinde büyük bir artış gözlenmiştir. Barzan, Dilim, Şammar ve Hemund gibi Kürt-Arap aşiretlerin gerçekleştirdiği adi hırsızlık ve yağmalama olayları halkı adeta canından bezdirmiştir. Nazım Paşa, güçlü otoritesi ile eşkıyalık meselesine son vermiştir ${ }^{14}$. Ancak takip eden yıllarda iç siyasal çekişmeler ve Birinci Dünya Savaşı'nın başlamasıyla birlikte eşkıyalık hareketleri yeniden başlamıştır.

Nazım Paşa, valiliği sırasında Basra Vilayeti Valisi İttihatçı Süleyman Nazif (19 Eylül 1909-7 Eylül 1910) ile yerel siyaset, aşiretlere karşı izlenecek yol ve yetki paylaşımı konularında anlaşmazlığa düşmüştür. Bu anlaşmazlık, Eylül 1910'da Süleyman Nazif' in istifasına neden olmuştur $^{15}$. Söz konusu istifa, İttihatçı-İttihatçı olmayan idareci tartışmasından öte, Irak bölgesindeki yetki sorununu bir kez daha gözler önüne sermiştir. Ayrıca Süleyman Nazif Bey, Basra' da kendisine Midhat Paşa'nın Bağdat Valiliği dönemindeki icraatlarını örnek almıştır. Süleyman Nazif, İttihatçıların yabancı nüfuzunu kırmayı amaçlayan merkeziyetçi siyasetinin Basra' daki uygulayıcısı olmuştur $^{16}$. Bu amaçla İngiliz nüfuzunun kırılmasına yönelik adımlar atılmış, Hindistan’da Osmanlı nüfuzunun artırılmasına yönelik çabalar sarf edilmiştir. Ayrıca bölgedeki diğer tehdit Şiiliğe karşı Sünni itikadını muhafaza ve müdafaa edecek müderrisler tayininde bulunmuştur ${ }^{17}$.

Nazım Paşa'nın azledilme olayı, II. Meşrutiyet Dönemi'nin genel özelliklerini yansıtmaktadır. Nazım Paşa'nın, Bağdat için oldukça uzun sayılabilecek, yaklaşık on altı aylık valilik dönemi, Dahiliye Nazırı Halil Paşa'nın dört sayfalık fezlekesi ile sona ermiştir. Nazım Paşa’ya isnat edilen suçlamalar; Vilayet içi atamalarda liyakate göre değil keyfi davranışlarda bulunması, Dilim eşkıyasından on dört kişiyi hiçbir gerekçe göstermeden salıvermesi, adliyede işkence iddialarını araştırmak için görevlendirilen memura hakaret etmesi ve 70.000 lira serveti bulunan nişanlı bir Ermeni kızını, yanında çalışan Sevren isimli bir görevliyle evlendirmek istemesi gibi pek de ciddiye alınacak türden değildir. Zira göreve gelir gelmez kısa süre içerisinde eşkıyalık olaylarına son vererek huzur ortamını yeniden tesis etmesi, ziraat faaliyetlerini artırması, imar

\footnotetext{
12 Artuç, a.g.m., s. 841-843; Bă̆gdat Vilayet Salnamesi 1329, (1913), s. 309.

13 Artuç, a.g.m., s. 843.

14 Artuç, a.g.m., s. 844-854.

15 Burcu Kurt, “Irak’ta Muktedir ve Müşteki Bir İttihatçı: Süleyman Nazif Bey’in Basra Valiliği’, Akademik Incelemeler Dergisi, C. 7, Sa., 2, Y11:2012, s. 172.

16 Kurt, “...Süleyman Nazif Bey’in Bağdat Valiliği”, s. 177178.

17 Kurt, “...Süleyman Nazif Bey’in Bağdat Valiliği”, s. 164-165.
} 
iskân faaliyetlerindeki başarıları nedeniyle Bağdat halkı, Nazım Paşa'nın azledilmesine büyük tepki göstermiştir. Her görüşten ve inanıştan yaklaşık 50.000 kişilik bir grup, Bağdat'ta toplanarak azledilme olayını protesto etmişlerdir. Halkın göstermiş olduğu sosyal tepki Bağdat tarihinde bir ilk olmuştur. Gösteriyle yetinmeyen Bağdatlılar, İstanbul'a çok sayıda telgraf çekerek Nazım Paşa'nın azledilmesinin haksız bir uygulama olduğunu, bu nedenle bir an evvel görevine iade edilmesi gerektiğini ifade etmişlerdir. Ancak söz konusu tepkiler Hükümet tarafindan dikkate alınmamıştır ${ }^{18}$.

Nazım Paşa'nın ayrılmasından sonra Bağdat Valiliği'ne Meclis-i Vükelâ'da kararıyla vekâleten Yusuf Paşa getirilmiştir. Bu arada ülkede iç siyasi dengeler çok çabuk yön değiştirmektedir. Nitekim İttihatçıların hâkim olduğu İbrahim Hakkı Paşa kabinesi, ülke genelinde yeniden yapılanma kararı almıştır. Söz konusu karar doğrultusunda İttihatçı olmayan vali ve kaymakamlar görevlerinden alınacak, yerlerine İttihatçı kadrolar tayin edilecekti. Yapılanma kararı bizzat eski Dâhiliye Nazırı Talat Bey tarafından alınmıştı. Yaklaşık üç ay kadar görev yapan Yusuf Paşa'nın yerine, 14 Haziran 1911'de Talat Bey'in önerileri doğrultusunda yeni Dâhiliye Nazırı Halil Bey'in de desteği sonucunda, İttihatçıların lider kadrosundan Cemal Bey atanmıştır. Atama kararı Cemal Bey'e, Dâhiliye Nazırı Halil Bey tarafından bizzat tebliğ edilmiștir. Meclis-i Vükelâ'da, 18 Temmuz 1911 de gerçekleştirilen toplantıda Cemal Bey'in yetki vazifelerine ilişkin bir mazbata hazırlanmıştır. Irak hattının önemine vurgu yapan söz konusu mazbatada bölgedeki sorunlar şu şeklide tespit edilmiştir: Memur seçiminde titiz olunacak, layık olmayanalar görevden el çektirilecek, Bağdat ve Basra vilayetleri tedbir amaçlı ortak hareket edecekler, Bağdat ve Basra'da üçer taburluk alay konuşlandırılacak, nehirlerde asayiş sağlanacak, en mühim mesele olan arazi meselesi hususunda incelemelerin neticesi doğrudan Bağdat Valisi'ne havale edilecek, vilayet genelindeki yolların inşası ve bayındırlık hizmetleri için 40.000 liralık bir bütçe tahsis edilecek, Basra ve Musul vilayetlerindeki sorunların çözüm yeri de Bağdat Valiliği olacaktır. Yukarıdaki bilgilerden de anlaşllacağı üzere Bağdat Vilayeti, Musul ve Basra ile adeta bir bölge valiliği olarak tanzim edilmiştir. Selefi gibi oldukça geniş yetkilerle donatılmış olan Cemal Bey, ilk iş olarak Nazım Paşa dönemindeki kadroları tamamen değiştirmiştir. Hatta bütün suçu Nazım Paşa'nın görevde kalmasını istemek olan Musevi Cemaati hahambaşısı Papu Efendi'yi bile azletmekten çekinmemiştir ${ }^{19}$.

Cemal Bey, vilayet genelinde yapmış olduğu incelemeler neticesinde, 1 Temmuz 1912'de kaleme aldığ 1 raporla y1llardır uygulanan Bağdat politikasını ağır şeklide eleştirerek görüş ve önerilerini şu şeklide sıralamıştır: "Bağdat'ta çok büyük sefalet yaşanmaktadır. Rumeli'deki en ücra kösseler bile Bağdat'tan daha iyi durumdadır. Halkın geçim sıkıntısı had safhadadır. Rumeli uslahatı için 500.000 lira kâfi iken, Băğdat'ta ıslahat için 5.000.000 lira dahi yeterli değildir. Gerekli tedbirler alınırsa Bağdat ülke ekonomisine katkr yapabilecek zenginliğe sahiptir. Bağdat'taki Arap milliyetçiliklerinin çılkış noktası olarak da yaşanan sefaleti göstermiş ve bölgede acilen geniş̧ kapsamlı bir reform sürecinin hayat geçirilmesinin adeta bir zaruret halini almuştı ${ }^{20}$."

Cemal Bey, Bağdat İngiltere Başkonsolosu ile ihtilaf yaşamıştır. İhtilafın temel nedeni vilayet içi yazışmalar olmuştur. Başkonsolosa resmi bir yazı gönderen Cemal Bey, vilayet

18 Geniş bilgi için Artuç, a.g.m., 857-867.

19 Nevzat Artuç, Cemal Paşa (Askeri ve Siyasi Hayatı), TTK Yay., Ankara 2008, s. 89-90.

20 Artuç, a.g.e., s. 92-93. BOA, DHMTV, 37/8, 18 Haziran 1328 (1 Temmuz 1912). 
dâhilindeki yazışmaların İngilizce değil, Fransızca ve Türkçe yapılmasını istemiştir. Bir diğer ihtilaf konusu ise İngiltere tebaasından olan Hindistanlı hacı adayların, konsolosun atadığı resmi memurlar eşliğinde Bağdat’a girmeleri sırasında yaşanmıştır. Meselenin İngiliz Başkonsolosu tarafından kasten çıkartıldığını düşünen Cemal Bey, yaşananların vilayetin itibarını düşürdüğünü, buna karşın konsolosun itibarını artırdığını iddia etmiştir. Cemal Bey’i istifanın eşiğinden döndüren olay, Dâhiliye Nezareti’nin Başkonsolosun atadığı resmi görevlilerin memurluklarını men etmesiyle çözüme kavuşabilmiştir. Takip eden günlerde Başkonsolosun Kazımiye'de vilayetin haberi olmadan mahkeme tesis etmesi ve muhtar tayininde bulunması Cemal Bey'i adeta ç1lgına çevirmiştir. Yaşanan diplomatik sorun üzerine, 26 Mayıs 1912'de Cemal Bey’i ziyaret eden İngiltere Başkonsolosu ile mahkeme ve muhtarlıkların lağvedilmesi, Konsoloslukça tayin edilen memurların resmi sıfatlarının kaldırılması ve Hükümet'in belirlediği kıyafetlerin giyilmesi hususunda mutabakata varılmıştır ${ }^{21}$.

Cemal Bey, yaklaşık on dört ay devam eden valilik görevinden, İttihatçı aleyhtarı Gazi Ahmet Muhtar Paşa Hükümeti ile yaşadığı görüş ayrılığı ile nedeniyle istifa etmek zorunda kalmıştır²2. Onun başarılı valiliği, iç siyasi çekişmeler nedeniyle yarıda kalmıştır. Bağdat'ta tam istikrar sağlanmışken, beklenmedik gelişmeler durumu tersine çevirmiştir. Öte yandan Trablusgarp Savaş1 nedeniyle çekilmek zorunda kalan İbrahim Hakkı Paşa Hükümeti yerine İttihatçıların hâkim olduğu Sait Paşa Hükümeti kurulmuştur. Ancak, 6 Mayıs 1912'de başlayan Arnavut isyanı, ülke içerisinde yeni bir oluşumu da beraberinde getirmiştir. Halâskâr Zâbitân Grubu adı verilen bu oluşumun amacı İttihat ve Terakki'yi devirmekti. Arnavutluk'taki gidişatın kötüye gitmesini firsat bulan Halaskarlar, Hürriyet ve İtilaf Fırkası'nın da desteğiyle Sait Paşa Hükümeti'ni düşürülmesinde etkin rol oynadılar. Yeni Hükümet, 22 Temmuz 1912'de Gazi Ahmet Muhtar Paşa tarafindan kurulmuştur. Bu dönemde ülke genelindeki İttihatçı idarecilere görevden el çektirilmeye başlandı. Suranın kendisine geleceğini çok iyi bilen Cemal Bey, 22 Temmuz-3 Ağustos 1912 tarihleri arasında görevinden istifa etmiştir ${ }^{23}$. Böylece II. Meşrutiyet Dönemi'nde, ülke genelinde olduğu gibi, Bağdat'ta da kısır iç siyasi çekişmelerin ne denli etkili olduğu bir kez daha gözler önüne serilmiş oldu.

Gazi Ahmet Muhtar Paşa Hükümeti, Cemal Bey’den boşalan valilik görevi için II. Abdülhamid'e yakın isimlerden Müşir Zeki Paşa'yı getirerek bir anlamda İttihatçılardan intikam almak istemiştir. Zeki Paşa, 25 Ağustos 1912'de Bağdat Valiliği’ne atanmıştır. Eylül-Ekim 1912'de tıpkı selefleri Nazım Paşa ve Cemal Bey gibi, olağanüstü yetkilerle donatılmıştır ${ }^{24}$. Ancak toplam yedi ay süren valilik döneminde, beklenmedik askeri ve siyasi gelişmeler nedeniyle herhangi bir icraat gerçekleştirememiştir. Birinci Balkan Savaşı'nın çıkması ve alınan mağlubiyetler Gazi Ahmet Muhtar Paşa Hükümeti'nin, 29 Ekim 1912'de düşmesine neden oldu. Zeki Paşa böylece en büyük destekçisini kaybetmiş oldu. Yeni Hükümet, Kasım başlarında yine II. Abdülhamid'e yakın isimlerden Kâmil Paşa tarafindan kuruldu. Yeni Hükümet, Zeki Paşa'ya herhangi bir müdahalede bulunmadı. Ancak, 23 Ocak 1913'te gerçekleştirilen Bâb-1 Âli Baskını ile iktidar tamamen İttihatçıların eline geçti. Mahmud Şevket Paşa tarafından kurulan İttihatçı Hükümet'in Zeki

21 Artuç, a.g.e., s. 93-96

22 Artuç, a.g.e., s. 98; Artuç, a.g.m., s. 865.

23 Artuç, a.g.e., s. 98.

24 Türkan Erbengi-Emin Kutluğ, Müşir Mehmed Zeki Paşa ve Belgelerle Ermeni Olayları, Kuşak Ofset, İstanbul 2005, s. 4. 
Paşa'ya sıcak bakması mümkün değildi. Bu gerçeğin farkında Zeki Paşa, 19 Mart 1913'te istifa ederek Bağdat'tan ayrılmıştır ${ }^{25}$. Nazım Paşa için yapılan gösteriler, kısmen de olsa Zeki Paşa için yapılmıştır. Ancak ilkinde Hükümet'in almış olduğu sert önlemlerin halkı yıldırması nedeniyle, bu tepkiler geniş çaplı olamamıştır'26.

\section{B-Birinci Dünya Savaşı'nda Bağdat Vilayet İdaresi}

Zeki Paşa'dan sonra valilik makamına getirilen Cavid Paşa, yaklaşık bir buçuk yıl sonra yine siyasi gerekçelerle görevden alınmışıı²7. Bu arada Karadeniz'de Rus limanlarının bombalanmasının ardından, 5 Kasım 1914'te Osmanlı Devleti'ne savaş açan İngiltere hem Irak petrolleri hem de Hindistan ile olan bağlantılarının güvenliği nedeniyle iki gün sonra Basra Körfezine asker çıkarmıştır. Kısa süre içerisinde ciddi bir direnişle karşılaşmadan kuzeye doğru ilerleyip Selman-1 Pak önlerine kadar ulaşmışlardır. Dâhiliye Nazırı Talat Bey'in önerisiyle, 29 Aralık 1914'te Süleyman Nazif Bey, Bağdat Valiliğì'ne atanmıştır.

\section{1-Irak Cephesi'nin Açılışı ve Bağdat Vilayet İdaresinde Değişiklik}

Birinci Dünya Savaşı'nda Irak Cephesi'nin nihai hedefi İran idi. Almanya tarafından ileri sürülen projenin ilk adımı olarak, Goltz Paşa, 28 Kasım 1914'te Türkiye'ye gönderilmiştir. Goltz Paşa, söz konusu projenin ikinci adımı olarak, 6 Ekim 1915'te VI. Ordu Komutanlığı'na atandı. 16 Kasım 1915 'te İstanbul'dan hareket eden Goltz Paşa, 21 Aralık 1915'te Bağdat'a ulaşt. İran üzerine yapılacak askerî harekâtın hazırlıklarına başladı ${ }^{28}$. Goltz Paşa, İran işgal planlarıyla uğraşırken, Irak cephesinde VI. Ordu'nun kontrolü fiili olarak Nurettin Bey'de oldu. Goltz Paşa, VI. Ordu Kumandanlı̆̆ı'nı daha önce Halil Bey'e teklif etmişti. Ancak Halil Paşa, savaş zamanı komuta kademesinin değiştirilmesinin uygun olmayacağını öne sürerek bu teklifi kabul etmemişti. Halil Paşa, İran üzerine yapılacak askerî harekâta, Bağdat'ın güvenliğini tehlikeye atacağı endişesiyle soğuk bakmış, ısrarla hatalı bir karar olduğunu ifade etmiştir. Fakat Enver Paşa, İran'da nüfuzunu artırmaya çalışan Almanya'nın baskısıyla Halil Paşa'nın uyarılarını dikkate almamıştır ${ }^{29}$. Halil Paşa ayrıca, İngiliz birliklerinin Irak-Filistin hattında inşa ettikleri demiryolları ile Hindistan'dan getirmiş oldukları takviye birlikler ile zırhlı araç, mühimmat ve yiyeceklerini cepheye kolaylıkla naklettiklerini, buna karşılık kendilerinin deve ve merkeplerle yapmış oldukları erzak-mühimmat sevkiyatının yeterli olmadığını ifade ederek tehlikenin boyutunu anlatmaya çalışmıştır ${ }^{30}$.

Bölgede mevcut olan VI. Ordu'nun İran seferi hazırlıklarına yönlendirilmesi nedeniyle, İngilizlere karşı yürütülecek harekât için, 26 Ağustos 1914'te Irak ve Havalisi Umum Kumandanlığı adıyla yeni bir askeri birim oluşturulmuştur. Yeni ordunun, 26 Ağustos 1914-20 Ocak 1915 tarihleri arasında ilk komutanı Cavid Paşa olmuştur. Bölgede yaşanan mağlubiyetler ve Cavid Paşa'nın

25 Artuç, a.g.e., s. 96-99.

26 BOA, DH. MTV, 32-2/43, 4 Haziran 1329(17 Haziran 1913); Artuç, a.g.m., s. 865.

27 BOA, DH. MTV, 37/8, 8 Mayıs/28 Temmuz 1330 (21 Mayıs/10 Ağustos 1914); Artuç, a.g.m., s. 866.

28 Mustafa Şahin, “Kutü'l-Ammare'den Malta'ya: Irak Cephesi 6'ncı Türk Ordusu Komutanlarının (Halil Kut Paşa ve Ali İhsan Sabis Paşa) Tutuklanma ve Sürgün ile Cezalandırılmaları", Unutulan Zafer: Kut'ül Ammare, 100. Yılında Yeniden Anlamak Sempozyumu, Harp Akademileri Komutanlığı Yay, İstanbul 2016, s. 294.

29 Taylan Sorgun, Halil Paşa Bitmeyen Savaş, Kum Saati Yay., İstanbul 2003, s. 135-136.

30 Sorgun, a.g.e., s. 141. 
isteği üzerine, 23 Aralık 1914-14 Nisan 1915 tarihleri arasında Süleyman Askeri Bey ${ }^{31}$, Şuaybe mağlubiyeti ve intihar olayından sonra, 20 Nisan 1915-10 Ocak 1916 tarihleri arasında Nurettin Bey ve 10 Ocak -19 Nisan 1916'da Halil Bey yeni ordunun komutanlığını üstlenmişlerdir. Irak ve Havalisi Umum Kumandanlığı, savaş şartları içerisinde kurulmuş, 19 Nisan 1916'da yine savaş şartları gereği yapılan düzenleme sonucunda lağvedilmiştir ${ }^{32}$. Irak ve Havalisi Kumandanlığı'nın Kasım-Aralık 1915 tarihleri arasındaki mevcudu 25.000 ile 35.000 arasındadır. Bölgede ayrıca Şammar, Zübeyir, Dilim ve Horasan aşiretlerinden kurulu Fazıl Paşa komutasında yaklaşık 7000 kişilik aşiret süvari alayları tesis edilmiştir ${ }^{33}$.

\section{2- Selman-ı Pak Zaferi}

Osmanlı Devleti, Irak'ta tıpkı Trablusgarp'taki gibi, bölge aşiretlerinden istifade etmeye çalışmış ancak çok fazla başarı elde edememiştir. Çünkü Trablusgarp ile Irak coğrafyasının aşiret ve kültür yapısı birbirinden çok farklıdır. Bölgede dikkat çeken diğer bir olay, Irak’ta uygulamaya konulan cihad çağrısı olmuştur. Çağrı, Müslüman aşiretler arasında olduğu gibi, İngiliz ordusundaki Hintli Müslüman askerler arasında da karşılık bulmuştur. Ayrıca Irak'ta adeta temel sorun haline gelmiş aşiretler arası mücadele ve eşkıyalık hareketleri, II. Meşrutiyet'in başlangıcında olduğu gibi sonunda da devlet otoritesinin sağlanması yönünde en önemli engel olarak göze çarpmaktadır ${ }^{34}$.

İngilizlerin, 1915 Şubat başlarında Basra üzerinden Bağdat' a yapmış oldukları askerî harekâtta Irak ve Havalisi Umum Kumandanı Süleyman Askeri Bey’in yaralanması üzerine Süleyman Nazif Bey, Dahiliye Nazırı Talat Bey’e hitaben, 14 Şubat 1915'te bir telgraf göndermiştir. Söz konusu telgrafta özetle şu hususlara dikkat çekilmiştir: Irak ve Havalisi Kumandanı Süleyman Askeri Bey’in, İngilizler ile Basra yakınlarında gerçekleştirilen ilk çarpışmada yaralandığını, doktorların en az bir ay süreyle kesinlikle hareket etmeyecektir şeklindeki raporunu işittiğini, elinde olsa Süleyman Askeri Bey'in yaralanmaması için hayatını feda edebileceğini, zira geride kalan zabitanın yetersiz olduğunu, İbni Suud'un ihaneti ile işlerin daha da zorlaştığını, bu nedenle acilen tedbir alınması gerektiğini ifade etmiştir. Süleyman Nazif Bey sözlerinin devamında; bölge halkının insanların meziyetlerinden ziyade mevkilerine önem verdiğini, Bağdat'a gönderilen Dağıstanlı Mehmet Fazıl Paşa'nın bu işin üstesinden gelemeyeceğini, İstanbul'dan Bağdat'a mesafenin uzak, ancak zamanın kısa olduğunu, siyasi olarak istediği makamlara geldiğini, hayatta bundan sonra bir beklentisinin olmadığını, dolaysıyla Süleyman Askeri Bey iyileşene kadar askeri harekâta kendisinin memur edilmesini, zira bölgedeki en büyük mülki amir olarak bunu istemesinin en doğal görevi ve hakk1 olduğunu söyleyerek, vaziyetin ciddiyetini ortaya koymuştur ${ }^{35}$. Ancak onun isteği Osmanlı yetkili makamlarınca kabul edilmemiştir. Süleyman Askeri Bey, yaklaşık bir aylık istirahatin ardından, henüz tam olarak iyileşemeden komutayı yeniden ele almıştır. 30 Mart 1915'te de Basra'ya iki saat mesafede bulunan Şuaybe namındaki müstahkem mevkide savunmaya çekilmiş İngiliz birliklerine

31 Mustafa Balcığlu, Teşkilat-ı Mahsusa'dan Cumhuriyet'e, Asil Yayın, Ankara 2004, s. 14; Orhan Avc1, Irak'ta Türk Ordusu 1914-1918, Vadi Yay., Ankara 2004, s. 28.

32 Mehmet Serez, "Kutü’l-Ammare Kuşatması ve General Feldmareşal Wilhelm Leopold Colmar Freiherr von der Goltz "Paşa”, Unutulan Zafer: Kut'ül Ammare, 100. Yllında Yeniden Anlamak Sempozyumu, Harp Akademileri Komutanlığı Yay, İstanbul 2016, s.219-226; Şahin, a.g.m., s. 294; Arşiv Belgelerine Göre Kût'ül-Amâre Zaferi, s. 43; Avc1, a.g.e., s. 29.

33 Şahin, a.g.m., s. 294.

34 Geniş bilgi için bkz. Avc1, a.g.e., s. 167-178 ve 184-193.

35 Arşiv Belgelerine Göre Kût'ül-Amâre Zaferi, s. 49-50. 
taarruzda bulunmuştur. Yaklaşık bir buçuk gün devam eden şiddetli çarpışmalar neticesinde, orduda görev almış yerli aşiretlerinin firarı nedeniyle Osmanlı Ordusu geri çekilmiştir. Irak ve Havalisi Kumandanı bu başarısızlığı kendine yakıştıramamış ve çok müteessir olmuştur. Bir süre sonra da acıya dayanamayarak intihar etmiş̦tir. Durumun vahametini kavrayan mülki erkân Dâhiliye Nezareti'ne başvurarak Musul'dan Azerbaycan'a gönderilen Halil Bey'in kumandanlığa tayini ile otorite boşluğunun bir an evvel doldurulmasını istemiştir. ${ }^{36}$ Halil Bey'in Bakü'de bulunması nedeniyle Irak ve Havalisi Kumandanlığı'na, 20 Nisan 1915 tarihli irade ile Miralay Nurettin Bey tayin edilmiştir ${ }^{37}$. O sırada Edirne'de farklı bir görevde bulunan Nurettin Bey, ancak 19 Mayıs 1915 'te Bağdat'a ulaşarak görevine başlayabilmiştir.

Ordu kademesinde beklenmedik değişimler yaşanırken, siyasette de çalkantılı bir dönem içerisine girilmişti. Bağdat Valisi Süleyman Nazif Bey, 28 Haziran 1915'te Meclis-i Vükelâ kararıyla, anlaşılmayan bir nedenle, görevinden azledilmiştir ${ }^{38}$. Yerine, 29 Haziran 1915 tarihli Sadaret tezkeresiyle bir gün önce Basra Valiliği'ne getirilen Nurettin Bey atanmıştır. ${ }^{39}$ Böylece Nurettin Bey hem Irak ve Havalisi Kumandanı hem Basra ve hem de Bağdat Valisi oldu. Bölgenin kaderine adeta tek başına hükmeden Nurettin Bey, öncelikle bazı aşiretler tarafından çıkartılmış isyanları bastırdı. Ardından üstün İngiliz kuvvetlerine karşı Selman-1 Pak mevziine kadar çekilip zaman kazanarak, birliklerin eksiklerini tamamlamaya çalışmıştır. Bu arada Bağdat'ı ele geçirmek üzere General Townsend komutasında harekete geçen İngiliz ordusu, 21 Kasım 1915'te Selman-1 Pak'ta Nurettin Bey komutasında konuşlanmış Türk birlikleri üzerine saldırıya geçmiş̧ir. Yaklaşık dört gün süren taarruz sonrasında, başarılı olamayan İngiliz birlikleri, Kût'ül Amâre'ye çekilerek savunmaya geçmişlerdir ${ }^{40}$.

\section{3- Kût'ül Amâre Zaferi}

Selman-1 Pak'ta elde edilen başarı, Irak Cephesi'ndeki en önemli Türk zaferleri arasında yer alarak tarihe geçmiştir ${ }^{41}$. Bu arada Goltz Paşa ile zaferin başlıca mimarı Nurettin Bey arasında fikir ayrılığı ve yetki çatışması yaşanmaktaydı. Mesela Goltz Paşa, Nurettin Bey'in kuşatma altındaki Kût'ül Amâre'ye taarruz planına karşı olup, İngiliz birliklerinin açlıkla teslim alınmasını tavsiye etmiş, mevcut birliklerinden bir kısmını İran'a kaydırmıştır. Goltz Paşa, İran'a gittiğinde Nurettin Bey taarruz harekâtını gerçekleştirmiştir. Nurettin Bey ayrıca uygulamalarını doğru bulmadığı ve Alman menfaatlerinin tesisi için çalışmakla suçladığı Goltz Paşa'yı Enver Paşa'ya şikâyet etmiş ancak bir netice alamamıştır. Nurettin Bey, 10 Ocak 1916'da birliklerine hitaben yayınlamış olduğu emirde Kût'ül Amâre'nin alınacağından hiç kuşkusu olmadığını kesin bir dille ifade etmiştir. Ancak aynı gün Goltz Paşa ile yaşadığı anlaşmazlık nedeniyle görevinden alınmışıır ${ }^{42}$. Nurettin Bey'in yerine Enver Paşa'nın amcası Halil Paşa, 07-09 Ocak 1916'da son Osmanlı Bağdat Valisi olmuştur. Ancak Halil Paşa'nın atama kararnamesinde mülki ve askeri idare açısından daha faydalı

36 Arşiv Belgelerine Göre Kût'ül-Amâre Zaferi, s. 55; Balcığlu, a.g.e., s. 14; Necati Fahri Taş, Nurettin Paşa, ATAM Yay., Ankara 2014, s. 17.

37 Arşiv Belgelerine Göre Kût'ül-Amâre Zaferi, s. 57.

38 BOA, İMM, 16 Kanun-1 evvel 1330 (29 Aralık 1914); Artuç, a.g.m., s. 866; Şuayıp Karakaş, Süleyman Nazif, Kültür ve Turizm Bakanlığ yay., Ankara 1988, s. 90-92.

39 Arşiv Belgelerine Göre Kût' ül-Amâre Zaferi, s. 61, 73.

40 Çetinsaya, a.g.m., s. 95.

41 Taş, a.g.e., s. 24-27.

42 Taş, a.g.e., s. 39-40. 
olacağına inanıldığından Basra Vilayeti Vali Vekilliği ve Bağdat Vilayeti Valiliği’ne tayini ibaresi dikkat çekmektedir ${ }^{43}$. Bölgedeki son Osmanlı idarecisi olan Halil Paşa, Goltz Paşa'nın 19 Nisan 1916'da tifüsten ölümünden sonra, 27 Nisan 1916'da asaleten VI. Ordu Kumandanlığı'na da tayin edilmiş, yaklaşık bir hafta kadar önce Irak ve Havalisi Kumandanlığı'nın lağvedilmesinin ardından bölgedeki yetki karmaşası da sona ermiştir ${ }^{44}$.

Bürokraside baş döndürücü gelişmeler yaşanırken, cephede savaş tüm hızıyla devam etmektedir. Kût'ül Amâre'deki kuşatmayı yarmak ve General Townshend komutasındaki birlikleri kurtarmak için Felahiye'de konuşlanmış Türk mevzileri üzerine, 21 Ocak 1916'da taarruz eden yeni İngiliz kuvvetleri başarısız olarak geri çekilmek zorunda kalmışlardır. İngilizler, yaklaşık bir buçuk ay kadar devam eden hazırlıktan sonra, 8 Mart 1916'da bu defa Sabis üzerine taarruz ettilerse de bir kez daha Türk ordusu tarafindan püskürtülmüşlerdir. Önce, 6 Nisan ve sonra da 22 Nisan'da Felahiye'de başlayan peş peşe iki İngiliz taarruzu yine kahraman Türk Ordusu tarafından başarıyla kırılmıştır. Artık Kût'ül Amâre'de kuşatma altındaki İngiliz birlikleri için kurtuluş ümidi ve teslim olmaktan başka çare kalmamıştır. General Townshend ve birliği, 29 Nisan 1916'da teslim alınarak Bağdat'a gönderilmişlerdir ${ }^{45}$.

\section{4-Yıldırım Ordular Grup Kumandanlığı'nın Kuruluşu ve Bağdat'ın Düşüşü}

Irak Cephesi'nde alınan başarılar kısa sürdü. VI. Ordu'nun ağırlığg İran tarafına vermesini firsat bilen İngilizler, 14 Aralık 1916'da Bağdat üzerine yeniden ve daha güçlü bir şekilde taarruza başlamışlar, büyük bir direnişle karşılaşmadan, 25 Şubat 1917'de Kût'ül Amâre'yi, 11 Mart 1917'de Bağdat'1 ele geçirmişlerdir. Halil Paşa, yaşanan acı mağlubiyetlerden sonra yeğeni Nuri Paşa'nın komutasındaki Kafkas İslam Ordusu ile Bakü’ye hareket etti46. Osmanlı Devleti, Bağdat'1 kaybetmeyi içine sindirememişti. İkinci Gazze Savaşı'nda İngilizlere karşı kazanılan kısmi başarıyla birlikte Bağdat'ın geri alınması söz konusu olmuştu. Bu fikir, bölgedeki nüfuzunu İngiltere'ye kaptırmak istemeyen Almanya tarafından destekleniyordu. Enver Paşa, mayıs ayı içerisinde Cemal Paşa'ya bir telgraf göndererek eski Alman Genelkurmay Başkanı Falkenhayn'ın birkaç ay sonra bölgeye bir inceleme gezisi yapacağından dolayı gerekli kolaylığın gösterilmesini rica etmiştir. Yaklaşık bir ay sonra da teftiş amacıyla Filistin Cephesi'ne gelmiştir. Enver Paşa, Cemal Paşa ile yaptığg görüşmede Bağdat'ı geri almak için II. Ordu Kumandanı Mustafa Kemal Paşa komutasında bir ordu teşkil etmek ve bu orduyu Halil Paşa komutasındaki VI. Ordu ile birleştirmek niyetinde olduğunu söylemiştir. Ancak IV. Ordu Kumandanı Cemal Paşa, Filistin tehlikede oldukça Bağdat üzerine yapılacak askerî harekâtın yanlış ve sakıncalı olacağı kanaatindeydi. Ona göre Bağdat Seferi'ni yapmaktansa Halep'te güçlü bir savunma bloğu oluşturmak daha mantıklı olacaktı. Zira bu sayede İngilizlerin Bağdat'tan ileri harekâtlarına karşı koyulabilecekti. Ancak Enver Paşa, Almanya'dan alınacak yardımın tehlikeye düşmemesi adına, Bağdat harekâtının yanında yer almıştır. Bu olay Enver Paşa ile Cemal Paşa'nın arasının açılmasına sebep olmuştur ${ }^{47}$. Enver

43 Başbakanlık Devlet Arşivleri Genel Müdürlüğü, Arşiv Belgelerine Göre Kût'ül-Amâre Zaferi, İstanbul 2016, s. 81; BOA, İMM, 25 Kanun-1 evvel 1331 (7 Ocak 1916); Artuç, a.g.m., s. 866.

44 Şahin, a.g.m., s. 294, 303-304, 331, 341, 351; Taş, a.g.e., s. 43; Arşiv Belgelerine Göre Kût'ül-Amâre Zaferi, s. 105, 121 ve 131; Serez, a.g.m., s. 232-238.

45 Mehmet Emin Dinç, Halil (Kut) Paşa'nın Askerî ve Siyasi Faaliyetleri, (Ege Üniversitesi Sosyal Bilimler Enstitüsü Tarih Anabilim Dalı Yayınlanmış Doktora Tezi), İzmir, 1998, s. 53-67.

46 Şahin, a.g.m., s. 305.

47 Artuç, a.g.e., s. 249-250. 
Paşa, kararlılığını göstermek amacıyla Kafkas Orduları Komutanı Hasan İzzet Paşa ile II. Ordu Komutanı Mustafa Kemal Paşa'yı çağırtarak bir toplantı yapmıştır. Söz konusu toplantıda Bağdat harekâtından geri dönüş olmayacağını, Yıldırım Ordular Grubu Kumandanlı̆̆ı'na Falkenhayn'ın tayin edileceğini kesin bir dille ifade etmiştir. Cemal Paşa bu karara karşı çıkmış, IV. Ordu Kumandanlığı'ndan istifa etmek istemiş, ancak Hasan İzzet Paşa'nın yoğun çabaları sonucunda bu kararından vazgeçirilmiştir ${ }^{48}$.

Cemal Paşa'nın Bağdat harekâtına muhalefeti Almanya'yı endişelendirmişti. Bu nedenle Cemal Paşa'nın Almanya seyahatine çıkartılması ve yokluğunda Yıldırım Ordular Meselesinin halledilmesine karar verilmiştir. Neticede Cemal Paşa, Alman İmparatoru'nun özel isteği ile Almanya'ya davet edilmiş, 25 Ağustos 1917'de de Almanya'ya hareket etmiş̧ir. Bu boşluktan istifade ile Falkenahyn Eylül başlarında Yıldırım Ordular Grubu Komutanlığı'na atanmıştır. Ancak Bağdat'1 İngilizlerin elinden almak mümkün olmamıştır. 09 Aralık 1917'de Kudüs'ün düşmesi, bütün ümitleri sona erdirmiştir. Falkenhayn, Kudüs'ün düşüşü bahane gösterilerek yaklaşık beş ay devam eden görevinden, 25 Şubat 1918'de azledilmiştir ${ }^{49}$.

Halil Paşa, Bağdat ve Basra'nın İngilizler tarafından işgali sonrasında, Temmuz 1918'e kadar yalnızca VI. Ordu Kumandanlığ görevini sürdürdü. Bu tarihten itibaren Şark Ordular Grubu Kumandanlığı'na tayin edildi. Harbiye Nazırı Enver Paşa'nın, 3 Temmuz 1918 tarihli öneri yazısı ve 6 Kasım 1918 tarihli irade ile IV. Kolordu Kumandanı Ali İhsan Paşa, VI. Ordu'nun son komutanı oldu. Yaklaşık yetmiş bir yıldır faaliyette olan VI. Ordu, 2 Şubat 1919'da lağvedildi ${ }^{50}$. İngilizler, Mayıs 1918'de Kerkük'ü Mondros Mütarekesi'nden sonra da Musul'u işgal etmişlerdir. Nihayet Irak, 1920 yılında San Remo Konferansı'nın ardından tamamıla bir İngiliz sömürgesi haline gelmiştir.

\section{Sonuç}

II. Meşrutiyet'in ilanı Bağdat'ta da olumlu karşılanmıştır. Yeni düzenin getirdiği belirsizlikler Bağdat'ta otorite boşluğunun doğmasına ve eşkıyalık hareketlerin sebebiyet vermiştir. İttihatçıllar sorunu çözmek amacıyla olağanüstü yetkili valilerin tayin edilmesine önem göstermişlerdir. Bağdat valileri aynı zamanda VI. Ordu Kumandanı oldular. Bu sayede yetki çatışması ya da çift başlılık sorunu ortadan kaldırılmış oldu. Bu dönemde Nazım Paşa ve Cemal Paşa gibi güçlü valiler görev yapmışlardır. Ancak bu defa da ülkedeki kısır iç siyasi çekişmeler, Bağdat'ta istikrar sağlanması yönünde en büyük engel olmuştur. Ayrıca İttihatçıların II. Abdülhamid'in meşihat usulünü kaldırıp Midhat Paşa'nın izinden gitmeleri, bölgede yeni sorunları beraberinde getirmiștir. Öte yandan Nazım Paşa'nın valilikten azledilmesi üzerine Bağdat’ta yapılan gösteri ve İstanbul'a çekilen yüzlerce telgraf, Meşrutiyet'in Bağdat'taki sosyal yapı üzerindeki etkisini göstermesi açısından ilgi çekicidir.

Bağdat'ta, XIX. Yüzyıl sonrasında İran dışında, İngiltere ve Almanya'nın da nüfuz mücadelelerine giriştiği görülmektedir. İngiltere'nin petroller ve Hindistan yolunun güvenliği hususundaki hassasiyetine, Almanya Berlin-Bağdat demiryolu projesiyle karşıllk vermişlerdir. İttihatçılar, tıpkı II. Abdülhamid döneminde olduğu gibi, Bağdat’ta İngiliz nüfuzuna karşı açıkça

48 Artuç, a.g.e., s. 250-251.

49 Artuç, a.g.e., s. 252-261.

50 Şahin, a.g.m., s. 294, 303-304, 331, 341, 351; Taş, a.g.e., s. 43; Arşiv Belgelerine Göre Kût'ül-Amâre Zaferi, s. 105, 121 ve 131; Serez, a.g.m., s. 232-238. 
cephe almışlardır. Birinci Dünya Savaşı'nın başlamasıyla birlikte Alman nüfuzu ağırlığını daha fazla hissettirmiş, Osmanlı Devleti'nin Bağdat politikasına yön vermeye çalışmıştır. Goltz Paşa'nın VI. Ordu Kumandanı olarak görevlendirilmesi, daha sonra Falkenhayn'ın Yıldırım Ordular Grubu Komutanı olarak bölgeye gelişi Alman nüfuzunun etkisini göstermesi açısından önemlidir. Alman komutanların sadece kendi ülkelerinin menfaatleri doğrultusunda hareket etmeleri, buna mukabil Türk komutanların can havliyle imparatorluğun parçalanmasına ve çökmesine engel olma çabaları, iki farklı kültüre mensup komuta heyeti arasında yetki çatışmasının ve fikir anlaşmazlığının yaşanmasını kaçınılmaz kılmıştır. Nurettin Bey ile Goltz Paşa, Cemal Paşa ve Mustafa Kemal ile Falkenhayn arasında yaşanan sorunları bu bağlamda değerlendirmek meselenin daha iyi anlaşılmasını sağlayacaktır. Öte yandan, 1917'de Bağdat'ın düşmesi ve takip eden yıllarda, Kerkük dahil, Irak coğrafyasının tamamen ele geçirilmesi İngiliz nüfuzunun üstünlüğünü tartışmasız ve rakipsiz olarak ortaya koymuştur.

\section{KAYNAKÇA}

Başbakanlık Osmanlı Arşivi

DH. MUI, $1 / 9$.

İMM, 25 Kanun-1 evvel 1331.

İMM, 16 Kanun-1 evvel 1330.

DH. MTV, 32-2/43, 37/8.

\section{Salnameler}

Bağdat Vilayet Salnamesi, 1329.

\section{Araştırma ve İncelemeler}

Başbakanlık Devlet Arşivleri Genel Müdürlüğü, Arşiv Belgelerine Göre Kûtü'l-Amâre Zaferi, İstanbul 2016.

ARTUÇ, Nevzat. Cemal Paşa (Askeri ve Siyasi Hayatı), TTK Yay., Ankara 2008.

, “Osmanlı Devleti’nin Son Dönem Irak politikasına Bir Örnek: Nazım Paşa’nın Bağdat Valiliği (25 Kasım 1909-15 Mart 1911), Belleten, C. LXXIV, Sa. 271, Aralık 2010, s. 833-870.

AVCI, Orhan Irak'ta Türk Ordusu 1914-1918, Vadi Yay., Ankara 2004.

BAYKAL, Bekir Sitkı. Mithat Paşa Siyasi ve İdari Şahsiyeti, T.C. Ziraat Bankası 100. Y11 Armağan1, İstanbul 1964.

BALCIOĞLU, Mustafa. Teşkilat-ı Mahsusa'dan Cumhuriyet'e, Asil Yayın, Ankara 2004.

ÇETINNSAYA, Gökhan “Irak XIX. Yüzyıl”, TDVIA, Y11: 1999, C. 19, s. 93-95.

, “II. Abdülhamid'in İç Politikası: Bir değerlendirme Denemesi", Osmanlı Araştırmaları, XLVII, 2016, s. 353-409.

ERBENGİ, Türkan -KUTLUĞ, Emin, Müşir Mehmed Zeki Paşa ve Belgelerle Ermeni Olaylarl, Kuşak Ofset, İstanbul 2005. 
SEREZ, Mehmet. "Kutü'l-Ammare Kuşatması ve General Feldmareşal Wilhelm Leopold Colmar Freiherr von der Goltz "Paşa", Unutulan Zafer: Kut'ül Ammare,100. Yllında Yeniden Anlamak Sempozyumu, Harp Akademileri Komutanlığı Yay, İstanbul 2016, s. 211-272.

ŞAHIN, Mustafa 'Kutü'l-Ammare'den Malta'ya: Irak Cephesi 6'nc1 Türk Ordusu Komutanlarının (Halil Kut Paşa ve Ali İhsan Sabis Paşa) Tutuklanma ve Sürgün İle Cezalandırılmaları", Unutulan Zafer: Kut'ül Ammare, 100. Yilında Yeniden Anlamak Sempozyumu, Harp Akademileri Komutanlığ Yay, İstanbul 2016, s. 291-353.

DINÇ, Mehmet Emin. Halil (Kut) Paşa'nın Askerî ve Siyasi Faaliyetleri, (Ege Üniversitesi Sosyal Bilimler Enstitüsü Tarih Anabilim Dalı Yayınlanmış Doktora Tezi), İzmir, 1998.

KARAKAŞ, Şuayıp Süleyman Nazif, Kültür ve Turizm Bakanlığı Yay., Ankara 1988.

KURT, Burcu. “Modernleşen Sanayi'ye Ayak Uydurmak: Osmanlı Irak'ında Kurulan Sanayi Mektepleri”, History Studies, Vol:5, İssue: 3, May 2013, pp. 151-173.

, "Meşihat Usulü’nün Ilgası: II. Meşrutiyet Dönemi Basra Vilayeti'nde Toprak reformu Teşebbüsleri”, OTAM, Sa. 37, Bahar 2015, s. 219-238.

, "Irak'ta Muktedir ve Müşteki Bir İttihatç1: Süleyman Nazif Bey'in Basra Valiliği”, Akademik Incelemeler Dergisi, C. 7, Sa., 2, Y11:2012, s. 155-179.

SORGUN, Taylan. Halil Paşa Bitmeyen Savaş, Kum Saati Yay., İstanbul 2003.

ŞERİF PAŞA, Bir Muhalifin Hatıralarl Nehir Yay., İstanbul 1990.

TAŞ, Necati Fahri. Nurettin Paşa, ATAM Yay., Ankara 2014. 